\title{
Effect of hay on performance of Holstein calves at suckling and post-weaning
}

\author{
Robson Kyoshi Ueno ${ }^{1}$, Mikael Neumann², Fabiano Marafon ${ }^{3}$, Marcela Ambrogit, \\ Balduino Adriano Daros ${ }^{5}$ Eduardo Pletz ${ }^{5}$ \\ http://dx.doi.org/10.1590/0034-737X201461050010
}

\begin{abstract}
The objective of this work was to evaluate the performance of Holstein calves in suckling and post-weaning phases, intensively managed during suckling in the absence or presence of hay. Twenty-four male Holstein calves, at an average age of 15 days and initial weight of $43 \mathrm{~kg}$ were used in the experiment. The experimental design was completely randomized, consisting of two treatments and six replications. The treatments were as follows: 1) suckling with milk substitute + initial concentrate for calves, ad libitum + temperate grass hay (oat/ryegrass), ad libitum; 2) suckling with milk substitute + initial concentrate for calves, ad libitum. No significant difference was found between treatments for weight gain and feed conversion. However, the supply of hay caused an increase in daily dry matter intake ( 2.127 vs $1.894 \mathrm{~kg})$. The intake of hay promoted greater stimulus to consumption of concentrate and greater weight at weaning.
\end{abstract}

Key words: concentrate, feed conversion, intake, roughage, weaning, weight gain.

\section{RESUMO}

\section{Efeito do feno no desempenho de bezerros holandeses em aleitamento e pós-desmame}

O objetivo deste trabalho foi avaliar o desempenho de bezerros holandeses nas fases de aleitamento e pósdesmame, manejados intensivamente na fase de aleitamento com ausência ou presença de feno. Foram utilizados 24 bezerros holandeses machos, com média de idade de 15 dias e peso inicial $43 \mathrm{~kg}$. O delineamento estatístico foi o inteiramente casualizado, constituído de dois tratamentos e seis repetições. Os tratamentos foram: 1) aleitamento com substituto lácteo + concentrado inicial para bezerros, ad libitum + feno de gramínea temperada (aveia e azevém), ad libitum; 2) aleitamento com substituto lácteo + concentrado inicial para bezerros, ad libitum. Não houve diferença significativa entre os tratamentos para ganho de peso e conversão alimentar. Entretanto, o fornecimento de feno causou aumento do consumo diário de matéria seca $(2,127$ vs 1,894 kg). A ingestão de feno promoveu maior estímulo ao consumo de concentrado e maior peso ao desmame.

Palavras-chave: concentrado, consumo, conversão alimentar, desmame, ganho de peso, volumoso.

Received: 10/26/2012; Approved: 02/25/2014.

'Veterinarian. Universidade Federal do Rio Grande do Sul, Rua Doutor Mário Lima Santos, n 403, 84.050-290, Ponta Grossa, Paraná, Brazil. robsonueno@ hotmail.com (corresponding author).

${ }^{2}$ Agronomist, Doctor. Universidade Estadual do Centro-Oeste, Rua Simeão Camargo Varela de Sá, nº 03, 85.040-080, Guarapuava, Paraná, Brazil. mikaelneumann @ hotmail.com ${ }^{3}$ Veterinarian. Universidade Estadual do Centro-Oeste, Rua Simeão Camargo Varela de Sá, nº 03, 85.040-080, Guarapuava, Paraná, Brazil. fabiano_marafon@ hotmail.com ${ }^{4}$ Undergraduate student. Universidade Estadual do Centro-Oeste, Rua Simeão Camargo Varela de Sá, nº 03, 85.040-080, Guarapuava, Paraná, Brazil. marcelamarcelinhaa @ hotmail.com ${ }^{5}$ Veterinarian. Universidade Estadual do Centro-Oeste, Rua Simeão Camargo Varela de Sá, nº 03, 85.040-080, Guarapuava, Paraná, Brazil. badvet@bol.com.br 


\section{INTRODUCTION}

It is known that the development of the rumen at an early age is closely associated with the intake of solid feed. It is also known that the concentrate, due to its unfolding into volatile fatty acids in the rumen, stimulates the development of the mucosa by increasing the size and the amount of ruminal papillae. However, roughages, such as hay, provide further development of the volumetric capacity of the rumen and increase in the muscle tissue of walls of the organ as well as it contributes to maintain the $\mathrm{pH}$ in the rumen (Paiva $\&$ Lucci, 1972).

It has been observed that in dairy farms, the technification and improvement of concentrate feeds, acquired for supplying the initial stage of calf growth, as the use of palatability and flavoring agents, growth promoters, powder milk, different sources of carbohydrates and fermentation rates, and micropellets, have favored an early consumption of solid foods by at satisfactory levels.

When concentrate feeds are provided early and $a d$ libitum, calves usually do not consume significant amounts of hay; thus it is commonly observed that the high quality hay become bed eventually. Calves have a high energy requirement, in contrast to its limited ability to consume solid feed. Thus, possibly by consuming a significant amount of hay, concentrate feed intake can be restricted, causing a body growth delay (Hill et al., 2008).

On the other hand, feeding of ruminants with high amounts of grains, even calves, can cause metabolic disturbances promoted by the fall in the rumen $\mathrm{pH}$, resulting primarily in a deficiency in nutrient absorption (Greenwood et al., 1997). In relation to roughages for calves, despite the recognized effect on the development of the rumen in size and musculature, deformities prevention in rumen papillae and keratinization of the mucosa, the recommendations on the age and way of supplying are conflicting and vague (Campos \& Liziere, 2005).

The introduction of forage in the diet of suckling calves has been long discouraged, especially by the hypothesis that its consumption would cause substitution effect of the initial roughage intake, modifying rumen fermentation and favoring the formation of acetate instead of propionate and butyrate causing a delay in the development of rumen papillae (Khan et al., 2011). In addition, roughage is energetically less dense than concentrates and its inclusion in the diet with a restricted amount of milk results in poor weight gain (Hill et al., 2008).

Interestingly, studies with roughage supply for calves younger than two weeks old reported improvements in animal performance (Thomas \& Hinks, 1982; Phillips, 2004; Khan et al., 2011; Castells et al., 2012.). Suckling protocols of calves are usually adjusted to provide milk equivalent to $10 \%$ of weight at birth. This amount can be gradually reduced or abruptly ceased at weaning. Recent studies has shown that higher amounts of substitutes or milk ( $20 \%$ of the weight at birth) promote increased growth rate, improve feed efficiency of animals (Brown et al., 2005) and decrease the incidence of disease (Khan et al., 2007).

Studies that evaluate the effect of roughage (hay) supply in intensive protocols of calves rearing with high amount of milk and starter concentrated are still scarce. Thus, Khan et al. (2011) evaluated the effect of offering hay to calves receiving eight liters of milk (approximately $20 \%$ of weight at birth) and starter concentrate $\mathrm{ad}$ libitum, and the authors concluded that the supply of chopped hay improved the total consumption of solid feed and had benefits for the physical development of the rumen-reticulum.

The objective of this study was to evaluate the performance of Holstein calves at suckling and postweaning, intensively managed during lactation, with the absence or presence of grass hay ad libitum on diet.

\section{MATERIALAND METHODS}

This experiment was carried out in the Animal Production Center (Núcleo de Produção Animal NUPRAN) at Universidade Estadual do Centro-Oeste UNICENTRO in Guarapuava, Paraná State, located in the subtropical zone of the state. The climate is altitude tempered, $\mathrm{Cfb}$ according to Köppen.

The specific objective of this study was to evaluate the effect of hay feeding to Holstein calves in suckling phase on the average daily weight gain (ADG), feed conversion (FC), daily dry matter intake (DDMI) and dry matter intake per $100 \mathrm{~kg}$ body weight (PDMI) at suckling and post-weaning phases.

The experimental diets in the suckling phase were as follows: $\mathrm{T} 1=$ suckling with milk substitute + starter concentrate for calves, ad libitum + temperate grass hay (oat/ryegrass), ad libitum; T2 = suckling with milk substitute + starter concentrate for calves, ad libitum. Both groups of animals received the same treatment in the post-weaning phase, which was hay temperate grass (oat and ryegrass) and the starter concentrate ad libitum.

Twenty-four male Holstein calves were used, at initial average age of 15 days and initial live weight of $43 \mathrm{~kg}$. The animals were housed in free stall facilities, consisting of 12 semi-covered stalls with $15 \mathrm{~m}^{2}$ of area each $(2.5 \mathrm{~m}$ $\mathrm{x} 6.0 \mathrm{~m}$ ), for every two animals, with plastic trough and and metal drinkers, regulated by automatic float. 
The experiment lasted 79 days, 9 days for adaptation to the diet and facilities and, sequentially, 5 assessment periods of 14 days each. Evaluations carried out in the suckling phase were performed from 24 to 65 days of life, when they were weaned. Performance of the animals was also evaluated for 28 days in the post-weaning phase, from 66 to 93 days of life. During this period, both groups were fed the same diet.

Solid food (hay and concentrate) were offered $a d$ libitum, divided into two tracts, at 6 a.m. and at 5 p.m. Animals had free access to water over the experiment. The hay was previously chopped using a stationary roughage processor, according to the methodology described by Heinrichs \& Kononoff (2002). After processing, hay had an average particle size of $10.67 \mathrm{~mm}$, in which $32 \%$ were larger than $19.0 \mathrm{~mm}, 40 \%$ were between $19.0 \mathrm{~mm} 8 \mathrm{~mm}, 22 \%$ were between 8.0 to 1.18 $\mathrm{mm}$ and $6 \%$ had particles smaller than $1.18 \mathrm{~mm}$.

The liquid feed was as follows: commercial milk substitute $\left(\right.$ Lactal $\left.^{\circledR}\right)$ associated with the commercial milk supplement $\left(\right.$ Maelk $^{\circledR}$ ), both of Nutron Alimentos Ltda. at a 75:25 ratio, respectively, diluted in pre-heated water at $45^{\circ} \mathrm{C}$ and provided in two daily meals at the same time solid feed was offered. The relationship established between the two supplements followed the recommendation of the manufacturer, in order to meet the requirements of vitamins and to promote the probiotic effect in the digestive tract of animals. The animals were fitted to the liquid diet before the experimental period.

Suckling protocol, considering the pre-experiment, the fiting and the experiment phases, was carried out as follows: from the $1^{\text {st }}$ to the $3^{\text {rd }}$ day of life (pre-experimental phase): supply of $4 \mathrm{~L}$ of colostrum per day; from the $4^{\text {th }}$ to the $6^{\text {th }}$ day of life (pre-experimental phase): 50 $\mathrm{g}$ of milk substitute, diluted in $4 \mathrm{~L}$ of milk per day; from the $7^{\text {th }}$ to the $8^{\text {th }}$ day of life (pre-experimental phase): $100 \mathrm{~g}$ of milk substitute, diluted in $1 \mathrm{~L}$ of water $+3 \mathrm{~L}$ of milk per day; from the $9^{\text {th }}$ to the $15^{\text {th }}$ day of life (preexperimental phase): $200 \mathrm{~g}$ of milk substitute, diluted in $2 \mathrm{~L}$ of water $+2 \mathrm{~L}$ of milk per day; from the $16^{\text {th }}$ to the $55^{\text {th }}$ day of life (experimental phase): $700 \mathrm{~g}$ of milk substitute, diluted in $4 \mathrm{~L}$ of water per day; from the $56^{\text {th }}$ to the $59^{\text {th }}$ day of life (experimental phase): $510 \mathrm{~g}$ of milk substitute, diluted in $3 \mathrm{~L}$ of water per day; and from the $60^{\text {th }}$ to the $65^{\text {th }}$ day of age (experimental phase): 340 $\mathrm{g}$ of milk substitute, diluted in $2 \mathrm{~L}$ of water per day.

Animals were gradually weaned, following protocol for suckling of free-stall managed calves, as recommended by Khan et al. (2007).

The milk substitute used for suckling calves was the commercial product Lactal ${ }^{\circledR}$, consisting of whole powder milk, powder milk serum, lactose, soy protein isolate, vegetable origin lipid, mineral vitamin premix, growth promoter additive, flavoring additive, antioxidant additive, coccidiostat additives. The assurance level of the product was $90 \%$ dry matter (DM); $21 \%$ crude protein (CP); $12 \%$ ether extract (EE); $0.90 \%$ fibrous matter (FB); $8 \%$ of raw mineral (MM), $0.6 \% \mathrm{Ca} ; 0.3 \% \mathrm{P}$ and $43 \%$ lactose.

In addition, milk substitute, Maelk ${ }^{\circledR}$ was used in association with milk substitute, recommended as feed supplement for calves. The product had in its composition: dextrose, lactose, powder whole milk, lipids of vegetable origin, soy protein isolate, silicates, milk serum, folic acid, lactic acid, pantothenic acid, prebiotic additive, antioxidant, choline chloride, decoquinate, niacin, palatability agent, probiotic, vitamin A, vitamin B1, Vitamin D3, Vitamin E, vitamin K3. The informed assurance levels were $90 \%$ DM, 20\% CP, $12 \%$ EE, $0.95 \% \mathrm{FB}, 12 \%$ of MM, $0.6 \% \mathrm{Ca}, 0.3 \% \mathrm{P}$ and $35 \%$ lactose.

The concentrate was manufactured in the animal feed mill of Cooperativa Agrária Agroindustrial, using in their preparation, the following feeds: soybean meal, soybean hulls, wheat bran, malt culms, barley, corn grains, corn germ, limestone, dicalcium phosphate, vitamin and mineral premix, salt and sodium monensin. The concentrate mixture presented in its analysis percentage average contents of $89.2 \% \mathrm{DM}, 22.0 \% \mathrm{CP}, 3.49 \% \mathrm{EE}, 8.27 \%$ FB, $12.15 \%$ of ADF, $20.74 \%$ of NDF, $7.42 \%$ MM, 1.1 $4 \% \mathrm{Ca}$ and $0.5 \% \mathrm{P}$.

The hay temperate grasses, composed by forage mixture of oat (Avena strigosa Schreb.), plus ryegrass (Lolium multiflorum Lam.) showed average contents of 92.45\% DM, 7.74\% CP, 2, 09\% EE, $63.43 \%$ NDF, $40.33 \%$ ADF and $3.98 \%$ of MM. Samples of concentrated feed and hay were analyzed according to the methodology suggested by Silva \& Queiroz (2002).

The animals were weighed at the beginning of the experiment and after, every 14 days, resulting in five 14day evaluation periods. Weighings were taken before liquid diet offer in the morning. The average values of ADG, DDMI and PDMI and FC were determined for each period. ADG was calculated as the difference between the initial and final weights, divided by the number of days in the period. The DDMI was recorded by weighing the offered feed and leftovers. The PDMI is the average value of DDMI in the period in percentage in relation to the average live weight of the animal in the period. FC is the ratio between DDMI and ADG in the period mean.

The experimental design was completely randomized, with two treatments and six replicates with repeated measures at time ( 5 periods). Each experimental unit was represented by a stall with two animals. The variables were submitted to analysis of variance, considering the sources of hay variation and period as well as their 
interaction. The differences between the two treatments were determined by $\mathrm{F}$ test at $5 \%$ of significance level, through the SAS (1993). Animal performance data were also submitted to polynomial regression analysis, considering the variable period (70 days) by means of proc reg in SAS (1993) program procedure.

The experiment was conducted meeting all the animal welfare and ethics principles with experimental animals. The research project was approved by the Ethics Committee on Animal Use of the Mid-West State Universtiy (Universidade Estadual do Meio-Oeste CEUA/UNICENTRO) according to the 028/2011 protocol.

\section{RESULTS AND DISCUSSION}

No significant interaction between supply of hay and evaluation periods was found the variables of animal performance and dry matter intake (Table 1). On the average, no significant differences between daily average gain and feed conversion were found, with mean values of $0.948 \mathrm{~kg}_{\text {animal }}{ }^{-1} \mathrm{day}^{-1}$ and $2.239 \mathrm{~kg}$ of DM intake for each $\mathrm{kg}$ of weight gain, respectively. The supply of hay in the suckling phase determined higher $(\mathrm{P}<0.05)$ DDMI (2.127 vs $1.894 \mathrm{~kg})$ and PDMI (2.82 vs $2.59 \%$ of live weight).

ADG of calves in the analysis of the periods, regardless of the presence of hay in the diet, showed linear increase of the order of $0.0105 \mathrm{~kg}$ for each day of advance in the evaluations. Similar behavior was observed for DDMI, with an increase of daily intake of the order of $0.0373 \mathrm{~kg}$ and $0.0144 \%$ of body weight for each day of advance in the evaluation period. Regarding FC, a quadratic behavior was observed, with the best transformation point of consumed dry matter into weight gain at age of calves of 38.5 days.

When evaluating two weaning ages (66 and 90 days of age), and two times of hay supply start (21 and 66 days of age) for dairy calves, Machado (2008) did not found any interaction between the factors on the daily dry matter intake, presenting an average of $1.37 \mathrm{~kg}$ day ${ }^{-1}$. Similarly, the consumption of starter concentrate did not change, reaching $0.818 \mathrm{~kg} \mathrm{day}^{-1}$, on average. The author also reported that consumption of hay was greater in animals fed hay in advance ( 0.185 vs $\left.0.115 \mathrm{~kg} \mathrm{day}^{-1}\right)$, and greater in animals weaned at 66 days of age $(0.175 \mathrm{vs}$ $0.125 \mathrm{~kg} \mathrm{day}^{-1}$ ) whereas dry matter intake per $100 \mathrm{~kg}$ of body weight did not change between treatments with an average of $2.1 \%$ until 96 days of age.

In the same experiment, Machado (2008) found no interaction between the treatments and hay supply time effect on average daily gain until 96 days of life $(0.698$ $\left.\mathrm{kg} \mathrm{day}^{-1}\right)$ and from 3 to 6 months of age of animals ( 0.947 $\left.\mathrm{kg} \mathrm{day}^{-1}\right)$. However, calves weaned at 66 days of age showed higher average daily gain until weaning $(0.645$ vs $0.515 \mathrm{~kg} \mathrm{day}^{-1}$ ), thanks to suckling protocol, which provided more milk for the animals at this phase. On the

Table 1. Average daily weight gain (ADG), dry matter daily intake expressed in $\mathrm{kg}$ animal (DDMI), in $100 \mathrm{~kg}$ live weight (PDMI), and feed conversion (FC) of Holstein calves in the suckling and post-weaning phases, supplemented with or without hay during the suckling phase.

\begin{tabular}{|c|c|c|c|c|c|}
\hline \multirow{2}{*}{ TREATMENT $^{1}$} & \multicolumn{4}{|c|}{ EVALUATION PERIODS (days of age) } & \multirow{2}{*}{ MEAN } \\
\hline & $1^{\text {st }}\left(24^{\text {th }}-37^{\text {th }}\right)$ & $2^{\text {nd }}\left(38^{\text {th }}-51^{\text {th }}\right) 3^{\text {rd }}\left(52^{\text {th }}-65^{\text {th }}\right)$ & $4^{\text {th }}\left(66^{\text {th }}-79^{\text {th }}\right)$ & $5^{\text {th }}\left(80^{\text {th }}-93^{\text {th }}\right)$ & \\
\hline \multicolumn{6}{|c|}{$\operatorname{ADG}\left(\mathrm{kg}\right.$ animal ${ }^{-1}$ day $\left.^{-1}\right)$} \\
\hline With hay & 0.390 & 1.155 & 1.208 & 1.051 & $0.977 \mathrm{a}$ \\
\hline No hay & 0.373 & 0.961 & 1.161 & 1.063 & 0.919 a \\
\hline \multirow{2}{*}{\multicolumn{6}{|c|}{$\frac{\text { ADG: } 0.5071+0.0105 \mathrm{D}\left(\mathrm{R}^{2}: 0.3901 ; \mathrm{CV}: 27.8 \% ; \mathrm{P}<0.0001\right)}{\text { DDMI }\left(\mathrm{kg} \mathrm{animal}^{-1} \text { day }^{-1}\right)}$}} \\
\hline & & & & & \\
\hline With hay & 1.061 & 2.096 & 2.710 & 3.123 & $2.127 \mathrm{a}$ \\
\hline No hay & 0.974 & 1.630 & 2.412 & 3.080 & $1.894 \mathrm{~b}$ \\
\hline \multirow{2}{*}{\multicolumn{6}{|c|}{$\begin{array}{c}\text { DDMI: } 0.4448+0.0373 \mathrm{D}\left(\mathrm{R}^{2}: 0.8667 ; \mathrm{CV}: 14.6 \% ; \mathrm{P}<0.0001\right) \\
\text { PDMI }(\% \text { live weight })\end{array}$}} \\
\hline & & & & & \\
\hline With hay & 2.25 & 2.90 & 3.05 & 3.05 & $2.82 \mathrm{a}$ \\
\hline No hay & 2.12 & 2.36 & 2.89 & 3.10 & $2.59 \mathrm{~b}$ \\
\hline Regression equation & \multicolumn{4}{|c|}{ PDMI: 2.1004 + 0.0144D (R²: 0.5063; CV: 10.8\%; P < 0.0001) } & \\
\hline \multicolumn{6}{|c|}{ FC (CMSD/ADG) } \\
\hline With hay & 2.880 & 1.853 & 2.271 & 3.012 & $2.310 \mathrm{a}$ \\
\hline No hay & 2.737 & $1.362 \quad 1.722$ & 2.088 & 2.933 & $2.168 \mathrm{a}$ \\
\hline Regression equation & \multicolumn{5}{|c|}{ FC: $4.0362-0.1232 \mathrm{D}+0.0016 \mathrm{D}^{2}\left(\mathrm{R}^{2}: 0.5993 ; \mathrm{CV}: 20.2 \% ; \mathrm{P}=0.0001\right)$} \\
\hline
\end{tabular}

${ }^{1}$ Periods 1, 2 and 3: artificial suckling phase; Periods 4 and 5: post-weaning phase.

Means followed by the same letter in the column do not differ statistically from each other by the $\mathrm{F}$ test at $5 \%$. 
other hand, later weaned calves presented higher daily average gain $\left(0.990\right.$ vs $\left.0.865 \mathrm{~kg} \mathrm{day}^{-1}\right)$ from 66 to 96 days of age. The author concluded that weaning should be performed at two months of age, coincident with the start of hay supply.

Khan et al. (2011) evaluated the performance of suckling Holstein calves, until 70 days of age, fed $8 \mathrm{~L}$ day $^{-1}$ of milk plus starter concentrate ad libitum, with or without hay supply. The authors found a higher $(\mathrm{P}=0.21)$ average daily gain in animals with access to hay $(0.88$ vs. $\left.0.82 \mathrm{~kg} \mathrm{day}^{-1}\right)$, emphasizing that on the first 35 days of age of the animals, there was no effect of hay supply daily dry matter intake. However, at 70 days of age, the animals presented daily dry matter intake of $3.0 \mathrm{~kg}$; the group fed hay presented higher $(P=0.006)$ daily dry matter intake, approximately $0.5 \mathrm{~kg} \mathrm{day}^{-1}$ higher than those which did not receive hay.

It can been seen in Table 2 the evolution of the live weight of the calves. The average initial weight was 44.1 $\mathrm{kg}$. Because of the slight numerical increase in average daily gain, in the end of the evaluation period, calves supplemented with hay in the suckling phase showed more $4.9 \mathrm{~kg}$ live weight than those that did not receive hay in the suckling phase.

According to Hoffman (1997), Holstein heifers for replacement, under optimal management conditions, must present body weight within the range of $105-110 \mathrm{~kg}$ at 3 months of age. According to Table 2, the calves that had hay available during the suckling phase exceeded the recommended limit for growth $(111.8 \mathrm{~kg})$ whereas calves that had no hay during the suckling phase slightly reached the minimum recommended body weight (106.9 kg).

On average, body weight of animals met the recommendations for 3 months of age. However, in the early phases, weights were beyond the recommendations. In the first phase of the experiment, the average daily gain was lower than the recommended by Hoffman (1997), probably due to problems of adaptation to experimental facilities. Nevertheless, in the subsequent periods, average daily gain was higher than the recommended, ensuring an adequate weight in the end of the experiment.

Similarly to the findings of this study, when evaluating the effect of hay supply, Khan et al. (2011) found no difference in body weight of the animals in the first five weeks of age. However, the group that consumed hay tended $(\mathrm{P}=0.08)$ to demonstrate a heavier body weight in the 6-10 weeks of age phase. Despite of that, at 70 days of age, animals fed hay had lower $(\mathrm{P}=0.34)$ empty body weight (93.6 vs $98.6 \mathrm{~kg}$ ). On the other hand, the supply of in the suckling phase provided higher $(\mathrm{P}=0.03)$ development of rumen-reticulum (empty weight: 1.89 vs 1.89) higher $(\mathrm{P}=0.36)$ concentrations of papillae (103.85 vs 93.45 papillae per $\left.\mathrm{cm}^{2}\right)$, higher $(\mathrm{P}=0.002)$ ruminal $\mathrm{pH}(5.46$ vs 5.06) and higher $(\mathrm{P}=0.18)$ concentration of beta-hydroxybutyrate in the blood.

Regarding food intake in the suckling phase, (Table 3), the intake of milk substitutes during the first two evaluation periods was equivalent between both treatments, in which animals were fed $0.7 \mathrm{~kg}$ animal ${ }^{-1}$ day $^{-1}$ until 51 days of life. From this, the supply of the milk substitute was gradually reduced, as a weaning strategy, presenting an average intake of $0.486 \mathrm{~kg}$ ani$\mathrm{mal}^{-1}$ day $^{-1}$ in the period. All calves consumed their daily quota of milk substitute over the experiment.

Feeding protocols for calves with high amount of milk may delay solid feed intake before weaning and promote poor consumption and body development after weaning. According to Khan et al. (2007), the gradual weaning can be a functional technique for stimulating solid feed intake from the beginning of the reduction in the milk supply. This can be seen in Table 3.

Regarding the consumption of hay during suckling, the animals fed roughage in this phase presented an increase in the intake as evaluation stages advanced, being 60, 73 and $143 \mathrm{~g}$ animal $^{-1}$ day $^{-1}$ in the first, second and third periods, respectively. However, in the post-weaning phase (Table 4), when animals received the same diet (more concentrated roughage), hay consumption was similar between groups.

In the overall evaluation period, the calves that received hay since the suckling phase presented a total hay intake of $9.0 \mathrm{~kg}$ whereas animals that were supplemented with hay after weaning consumed only 4.7 $\mathrm{kg}$, demonstrating an intake of $4.3 \mathrm{~kg}$ animal $^{-1}$ more hay for the treatment that received roughage since the suckling phase.

As for the consumption of concentrated feed, supply of hay since suckling promoted higher intake of concentrate in all evaluated periods. During the first three periods, that is, in the suckling phase (Table 3), the group

Table 2. Evolution of the body weight of calves supplemented with or without hay in the suckling phase according to the evaluation periods

\begin{tabular}{lcccccc}
\hline \multirow{2}{*}{ Treatments } & \multicolumn{7}{c}{ AGE (days of age) } \\
\cline { 2 - 7 } & $\mathbf{2 4}$ days & $\mathbf{3 7}$ days & $\mathbf{5 1}$ days & $\mathbf{6 5}$ days & $\mathbf{7 9}$ days & $\mathbf{9 3}$ days \\
\hline With hay & 44.5 & 50.0 & 64.0 & 80.2 & 97.1 & 111.8 \\
No hay & 43.7 & 48.9 & 62.3 & 75.8 & 92.0 & 106.9 \\
Mean & 44.1 & 49.4 & 63.2 & 78.0 & 94.6 & 109.4 \\
\hline
\end{tabular}

Rev. Ceres, Viçosa, v. 61, n.5, p. 668-674, set/out, 2014 
that had received hay presented an intake of $42.01 \mathrm{~kg}$ animal $^{-1}$ of concentrate, which represented an intake of $9.1 \mathrm{~kg}$ animal ${ }^{-1}$, higher than the $32.91 \mathrm{~kg}$ animal $^{-1}$ consumed by the group that did not receive hay.

In the post-weaning (Table 4) period, calves fed hay during suckling phase reached a concentrate intake of $87.3 \mathrm{~kg}$ animal ${ }^{-1}$, higher by $5.6 \mathrm{~kg}$ animal ${ }^{-1}$ than the 81.7 $\mathrm{kg}$ animal ${ }^{-1}$ presented by those fed hay only after weaning. In the total period of experiment, the calves that consumed hay since the suckling phase reached an intake of $129.3 \mathrm{~kg}$ animal-1 $^{-1}$ of concentrate, representing an intake of $14.7 \mathrm{~kg}^{-1}$ more than the animals that had access to hay since weaning $\left(114.6 \mathrm{~kg}\right.$ animal $\left.{ }^{-1}\right)$. In contrast, Hill et al. (2008) found a reduction in the concentrate intake in calves fed $5 \%$ hay.

Weaning has been traditionally recommended for Holstein calves when the animals present a concentrate intake of approximately $0.700 \mathrm{~kg} \mathrm{day}^{-1}$ for three consecutive days (Quigley III, 1996). Moreover, another suitable indicator for decision making regarded to weaning would be observed when the animals present a of $1.5 \%$ of their weight at birth (Greenwood et al., 1997). Based on these concepts, the animals of this experiment showed full conditions for weaning.

Khan et al. (2011) found in experiments previously described an initial consumption of hay ( 5 weeks) similar to this experiment, with values below $100 \mathrm{~g} \mathrm{animal}^{-1}$ day $^{-1}$. However, after ten weeks of age, the animals showed consumption of approximately $650 \mathrm{~g} \mathrm{day}^{-1}$. At 70 days of age, they found a consumption of $3.0 \mathrm{~kg}$ animal ${ }^{-1} \mathrm{day}^{-1}$ of the starter concentrate and, although there was no statistical difference, the animals that did not receive hay showed a trend towards higher consumption of the starter concentrate $(\mathrm{P}=0.10)$, different from that observed in this experiment.
It is suggested that feeding calves only with starter feed can reduce ruminal $\mathrm{pH}$, decreasing the motility of the rumen and cause hyperkeratinization and agglomeration of rumen papillae and thereby decrease the ability of the ruminal mucosa to absorb nutrients, particularly if the starter concentrate is finely ground (Greenwood et al., 1997). The starter concentrate offered in this experiment was finely ground since this is prerequirement for micropeletizing process to which it was submitted. This factor may have led the animals that did not have access to forage to the disorders listed above and it is the determinant factor for the increased consumption by animals with access to forage.

The higher consumption of concentrated feed found in animals that had hay available since suckling phase may be related to higher intake capacity, promoted by higher ruminal volume, as well as for maintaining the $\mathrm{pH}$ in this compartment. Moreover, the higher consumption can be the determining factor for most of the body development achieved in this group of animals

Table 4. Effect of hay supply in the suckling phase on feed intake in the post-weaning phase on the fresh matter basis.

\begin{tabular}{|c|c|c|c|}
\hline \multirow{2}{*}{ Treatments } & \multicolumn{2}{|c|}{ Feed intake (kg animal ${ }^{-1}$ day $\left.^{-1}\right)$} & \multirow{2}{*}{ Total } \\
\hline & Concentrate & Hay & \\
\hline \multicolumn{4}{|c|}{$4^{\text {th }}$ Period (from the $66^{\text {th }}$ to the $79^{\text {th }}$ day of age) } \\
\hline With hay & 2.868 & 0.177 & 3.045 \\
\hline No hay & 2.571 & 0.140 & 2.710 \\
\hline Mean & 2.720 & 0.159 & 2.878 \\
\hline \multicolumn{4}{|c|}{$5^{\text {th }}$ Period (from the $80^{\text {th }}$ to the $93^{\text {rd }}$ day of age) } \\
\hline With hay & 3.369 & 0.190 & 3,559 \\
\hline No hay & 3.266 & 0.194 & 3.461 \\
\hline Mean & 3.318 & 0.192 & 3.510 \\
\hline
\end{tabular}

Table 3. Effect of hay supply in the suckling phase on feed intake in the starter phase on a fresh matter basis.

\begin{tabular}{|c|c|c|c|c|c|}
\hline \multirow{2}{*}{ Tratments } & \multicolumn{4}{|c|}{ Feed Intake (kg animal ${ }^{-1}$ day $\left.^{-1}\right)$} & \multirow{2}{*}{ Total } \\
\hline & Milk substitute & Milk supplement & Concentrate & Hay & \\
\hline \multicolumn{6}{|c|}{$1^{\text {st }}$ Period (from the $24^{\text {th }}$ to the $37^{\text {th }}$ day of age) } \\
\hline With hay & 0.500 & 0.200 & 0.345 & 0.060 & 1.105 \\
\hline No hay & 0.500 & 0.200 & 0.311 & 0.000 & 1.011 \\
\hline Mean & 0.500 & 0.200 & 0.328 & 0.060 & 1.058 \\
\hline \multicolumn{6}{|c|}{$2^{\text {nd }}$ Period (from the $38^{\text {th }}$ to the $51^{\text {st }}$ day of age) } \\
\hline With hay & 0.500 & 0.200 & 0.991 & 0.073 & 1.764 \\
\hline No hay & 0.500 & 0.200 & 0.756 & 0.000 & 1.456 \\
\hline Mean & 0.500 & 0.200 & 0.874 & 0.073 & 1.610 \\
\hline \multicolumn{6}{|c|}{$3^{\text {rd }}$ Period (from the $52^{\text {nd }}$ to the $65^{\text {th }}$ day of age) } \\
\hline With hay & 0.286 & 0.200 & 1.665 & 0.143 & 2.295 \\
\hline No hay & 0.286 & 0.200 & 1.284 & 0.000 & 1.771 \\
\hline Mean & 0.286 & 0.200 & 1.475 & 0.143 & 2.033 \\
\hline
\end{tabular}


compared with the group receiving hay only after weaning.

Lizieire et al. (2002) found significant differences in the consumption of concentrate when providing roughage in the diet for calves; however no significance was observed in the daily weight gain. Animals in a diet with starter concentrate and chopped green pasture had lower concentrate intake than animals in diet with concentrate and hay, or only concentrate.

Castells et al. (2012), when evaluating several sources of forage in the diets of suckling Holstein calves, found that compared with the control diet, consisting only of the starter concentrate, animals that received oat hay, triticale silage or straw of barley consumed more starter concentrated $(0.88$ vs 1.14 ; $1.17 ; 1.06 \mathrm{~kg} \mathrm{day}^{-1}$, respectively), and had higher average daily gain $\left(0.72\right.$ vs $0.93 ; 0.88 ; 0.88 \mathrm{~kg} \mathrm{day}^{-1}$, respectively). The authors state that animals fed barley straw, corn silage or triticale silage had lower forage intake than those fed chopped alfalfa or oat hay. The supply of ryegrass hay, corn silage or chopped alfalfa improved protein digestibility compared with the control diet. Therefore, it is concluded that the correct choice of forage source for calves may improve intake of the starter diet and performance with no harm on the digestibility of dry matter.

\section{CONCLUSIONS}

In intensive feeding systems for rearing milk breed suckling calves, the supply of grass hay during the suckling phase increased by $12 \%$ the daily intake of dry matter and had no negative effect on weight gain and feed conversion, ensuring greater certainty in the application of early weaning in animals managed in that way.

\section{ACKNOWLEDGMENTS}

The authors thank Núcleo de Produção Animal (NUPRAN-UNICENTRO), Instituto Paranaense de Assistência Técnica e Extensão Rural (EMATER-PR), Cooperativa Agrária Agroindustrial and Nutron Alimentos.

\section{REFERENCES}

Brown EG, Vandehaar MJ, Daniels KM, Liesman JS, Chapin LT, Forrest JW, Akers RM, Pearson RE \& Nielsen MS (2005) Effect of increasing energy and protein intake on mammary development in heifer calves. Journal Dairy Science, 88:595-603.

Campos OF \& Lizieire RS (2005) Criação de bezerras em sistemas de produção de leite. In: III Simpósio Mineiro de Nutrição de Gado de Leite, Belo Horizonte. Anais, UFMG. p.44-59.

Castells LI, Bach A, Araujo G, Montoro C \& Terré M (2012) Effect of different forage sources on performance and feeding behavior of Holstein calves. Journal Dairy Science, 95:286-293.
Greenwood RH, Morril JL, Titgemeyer EE \& Kennedy GA (1997) A new method of measuring diet abrasion and its effect on the development of the forestomach. Journal Dairy Science, 80:2534-2541.

Heinrichs PJ \& Kononoff PJ (2002) Evaluating particle size of forages and TMRs using the New Penn State Forage Particle Separator. State College, The Pennsylvania State University. 14p.

Hill TM, Bateman HG, Aldrich JM \& Schlotterbeck RL (2008) Effects of the amount of chopped hay or cottonseed hulls in a textured calf starter on young calf performance. Journal Dairy Science, 91:26842693.

Hoffman PC (1997) Optimum body size of Holstein replacement heifers. Journal Animal Science, 75:836-845.

Khan MA, Lee HJ, Lee WS, Kim HS, Ki KS, Hur TY, Suh GH, Knag SJ \& Choi YJ (2007) Structural growth, rumen development, metabolic and immune response of Holstein male calves fed milk through stepdown and conventional methods. Journal Dairy Science, 90:33763387.

Khan MA, Weary DM \& Von Keyserlingk MAG (2011) Hay intake improves performance and rumen development of calves fed higher quantities of milk. Journal Dairy Science, 94:3547-3553

Lizieire RS, Cunha DNFV, Martuscello JA \& Campos OF (2002) Fornecimento de volumoso para bezerros pré-ruminantes. Ciência Rural, $32: 835-840$

Machado HVN (2008) Desempenho produtivo de bezerros holandeses submetidos a diferentes idades de desaleitamento e de fornecimento de feno. Dissertação de Mestrado. Universidade Federal de Viçosa, Viçosa. 26p.

Paiva JAJ \& Lucci CS (1972) Alimentação de bezerros com mistura concentrada comum + feno de soja perene. II Desenvolvimento dos pró-ventrículos. Boletim da Industria Animal, 29:151-159.

Phillips CJC (2004) The effects of forage provision and group size on the behavior of calves. Journal Dairy Science, 87:380-1388.

Quigley III JD (1996) Feeding prior to weaning. In: Calves, Heifers and Dairy Profitability National Conference, Ithaca. Proceedings, Northeast Regional Agricultural Engineering Service Cooperative Extension. p.245-255.

Sas Institute - Statistical Analysis System (1993) SAS/STAT user's Guide: statistics. Version 6. $4^{\mathrm{a}}$ ed. North Caroline. 943p.

Silva DJ \& Queiroz AC (2002) Análise de alimentos: métodos químicos e biológicos. $3^{\text {a }}$ d. Viçosa, UFV. 235p.

Thomas DB \& Hinks CE (1982) The effect of changing the physical form of roughage on the performance of the early-weaned calf. Animal Production, 35:375-384. 